\title{
Strategy for Improving The Work Discipline of Village Apparatus in Sidenreng Rappang Regency
}

\author{
Pratiwi Ramlan \\ Muhammadiyah University Sidenreng Rappang, Indonesia (email: pratiwiramlan.umsrappang@gmail.com) \\ Sapri Tajuddin \\ Muhammadiyah University Sidenreng Rappang, Indonesia \\ Khaeriyah Adri \\ Muhammadiyah University Sidenreng Rappang, Indonesia \\ Mardhatillah Devi Febrianti \\ Muhammadiyah University Sidenreng Rappang, Indonesia
}

\begin{abstract}
The purpose of this study was to analyze and determine strategies for improving the work discipline of village officials in Sidenreng Rappang Regency. This research was conducted in Carawali Village, Sidenreng Rappang Regency. The method used in this research is a qualitative approach (qualitative research). Data collection was carried out by means of observation and in-depth interviews. The primary data source in this study consisted of key informants, namely the Head of the Carawali Village and the informants in this study were officials / employees of the Carawali Village, Sidenreng Rappang District, obtained through the purposive sampling method. The data analysis technique uses the SWOT analysis method which is one of the methods used to describe the condition of a problem, and evaluate the problem, which is based on internal and external factors, namely Strengths, Weaknesses, Opportunities and Threats which then create a matrix. and assessment to find out the most appropriate strategy. Based on the results of this study, the most appropriate strategy to improve the work discipline of the Carawali Village Officials in Sidenreng Rappang District is to improve village apparatus services by conducting leadership training, utilizing human resources to participate in training in improving quality to use information system technology, improving coordination and supervision of village heads with other village officials, making clear SOPs on the rules and salary system to be applied.
\end{abstract}

\section{Keywords:}

strategy; work discipline; village apparatus; swot analysis

\section{Introduction}

The application of regional autonomy makes the revitalization of decentralization very important in the context of improving the performance of the government bureaucracy, provision and services so as to spur increased efficiency and strengthening competitiveness. 
In this regard, the decentralization of government bureaucracy, the provision and services to the community in a real, efficient and responsible manner needs to be accelerated further by referring to the direction and policies of regional autonomy decentralization (Dewi,2017). In line with the enactment of Law No. 32 of 2004 concerning Regional Government has a logical consequence for the Regional Government, namely the empowerment of the apparatus to be more professional, responsive and transparent. Given this fact, improving the quality of human resources is a definite need. The increasing need for civil servants aims to change their behavior into behavior capable of carrying out activities in all fields, because basically human behavior can influence every action in achieving the goals to be achieved (Istiqomah, 2017).

The issue of quality human resources is a very important issue in today's competitive era. The maximum empowerment of human resources will enable an organization to be able to compete by producing efficiency and effectiveness in its production process. One of the components of human resources that is so vital to an organization is employees. Where every organization, employees have an important role in order to achieve organizational goals, so that every employee is required to work optimally with effectiveness and efficiency, which in order to produce a quality employee requires empowerment (Jaitun,2013).

An alternative to increasing the empowerment of these employees is to increase work discipline (Mulyanto,2020). The existence of work discipline is very important because in a disciplined work atmosphere an office can carry out work programs that have been planned. Work discipline will be closely related to work regulations formulated by an organization or office. These regulations will be a reference for employees to become a common guide and at the same time to unite and align various goals and individual values held by employees (Mustika,2013).

Employee discipline is someone's behavior in accordance with the rules, existing work procedures or discipline is the attitude, behavior and actions in accordance with the rules of the organization, both written and unwritten. Work discipline is a tool used by managers to communicate with employees so that they are willing to change a behavior as well as an effort to increase one's awareness and willingness to comply with all company regulations and prevailing social norms (Puspasari, 2017). Another definition of discipline is a procedure that corrects or punishes for violating a rule or procedure while work discipline is influenced by factors which are also an indicator of work discipline, namely: 
1. Punctuality, employees come to the office on time, orderly and regularly, so it can be said that work discipline is good.

2. Using office equipment properly, and being careful in using office equipment, can show that a person has good work discipline, so that office equipment can avoid damage.

3. High responsibility, employees who always complete their assigned tasks according to procedures and are responsible for work results, can also be said to have good work discipline.

4. Compliance with office rules.

Employees wear office uniforms, use identification cards, make permits when not entering the office, are also a reflection of high discipline.

Carawali Village, Watang Pulu District, Sidenreng Rappang Regency, which is located on the Makassar-Tana Toraja tourism route. Carawali Village is a stopover village for domestic and foreign tourists, besides that there is also a traditional Lipa Sabbe (Silk Sarong) weaving center, the monument to the heroes of A. Cammi, a historical place, the Celli'e river, the beauty of iguanas and the ecosystem in it and the expanse. rice fields that stretch very wide, then the Village of Carawali as an agro-tourism village towards an environmental tourism village. Carawali Village is one of the places where the fighters in Sidenreng Rappang during the resistance against the invaders to formulate tactics and strategies, so that the name Carawali has been retained until now.

Village government administration activities in Carawali Village are carried out by village officials with a total of 12 people, consisting of the village head and village officials. The implementation of village government services will run and be better directed and even more advanced if the work discipline of all village officials in providing services follows the rules that have been set. Carawali village officials still often enter the office not on time, wear clothes that are not according to what is stipulated, in community service is still slow, causing complaints from the community being served.

The purpose of this research is to find out the right strategy to improve the work discipline of the village apparatus of Carawali, Watangpulu District, Sidenreng Rappang Regency. The way to get the right strategy is to use a SWOT analysis, namely Strength, Weakness, Opportunity and Threats. For Strengths and Weakness the factors come from the internal organization, while Opportunity and Threats come from outside the organization. 


\section{Methods}

This research uses a qualitative approach, which is research that intends to understand the phenomena experienced by research subjects such as behavior, perception, motivation, action, etc. holistically and by means of descriptions and forms of words and language, in a context. special nature and by utilizing various natural methods .

Data collection was carried out by means of observation and in-depth interviews. The primary data source in this study consisted of key informants, namely the Head of the Carawali Village and the informants in this study were officials / employees of the Carawali Village, Sidenreng Rappang District, obtained through the purposive sampling method. The data analysis technique uses the SWOT analysis method which is one of the methods used to describe the condition of a problem, and evaluates the problem, which is based on internal (internal) and external (external) factors, namely Strengths, Weaknesses, Opportunities and Threats which then create a matrix. and assessment to determine the most appropriate strategy (Ngindi,2018).

\section{Results and Discussion}

\section{Discipline Improvement Strategy with SWOT Analysis}

Based on data obtained from interviews with village officials, the lack of work discipline is due to the leadership supervision system, in this case the village head is lacking, is not firm in directing work and cannot be an example to his subordinates. Another main cause of lack of discipline is the unclear system of compensation / salary or wages to village officials, both in terms of the amount of salary and the timing of the payment of the salary that is not correct. This ultimately led to the village apparatus not following the rules that had been established in Carawali Village. Another thing that happens is that the village apparatus always arrives late and leaves earlier than the set working hours on the grounds that the community only comes at certain hours. The less than optimal service eventually caused complaints from the community who received services from the Carawali village office. For this reason, a strategy is needed to improve the work discipline of village officials in Carawali Village. 
The purpose of increasing and fostering work discipline is to fulfill the goals of the work discipline itself so that work implementation becomes more effective and efficient. Basically, work discipline development aims to create an orderly, orderly condition and work implementation can be carried out in accordance with predetermined rules. In this study, the aim of increasing work discipline refers to the optimal service of village apparitions so as to improve the performance of the Carawali village apparatus.

The strategy to increase work discipline is to use SWOT analysis techniques, using SWOT analysis, the results of the analysis which include strengths, weaknesses, opportunities and threats for Carawali Village, are:

\section{Table 1.}

The SWOT Analysis Table for the Carawali Village Apparatus

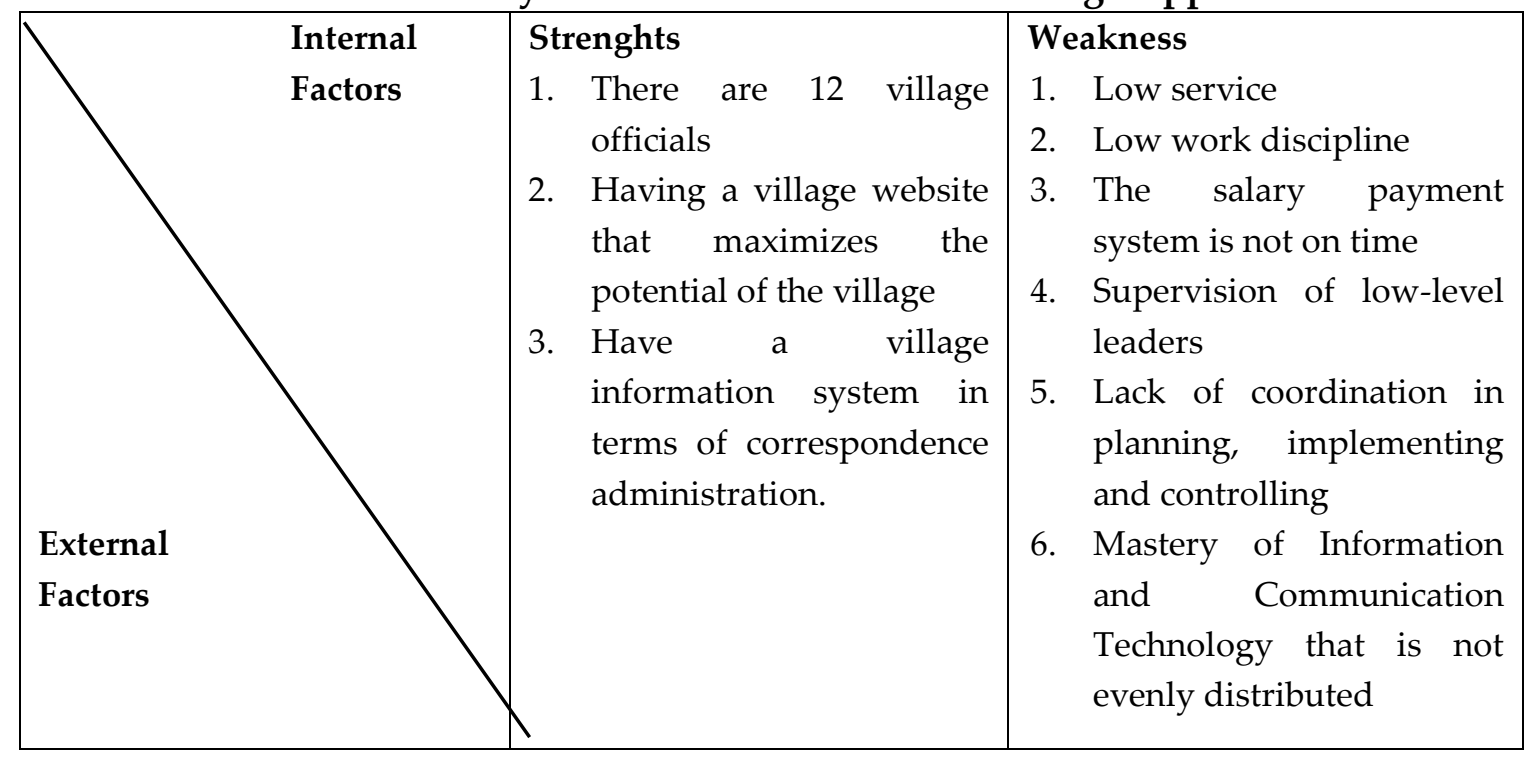




\begin{tabular}{|c|c|c|}
\hline $\begin{array}{l}\text { Opportunity } \\
\text { 1. Increase supervisory } \\
\text { supervision } \\
\text { 2. Provide leadership } \\
\text { training } \\
\text { 3. Local government review }\end{array}$ & $\begin{array}{l}\text { SO (Strenghts \& } \\
\text { Opportunity) } \\
\text { 1. Empower human } \\
\text { resources in improving } \\
\text { Information and } \\
\text { Communication } \\
\text { Technology in assisting } \\
\text { the performance of } \\
\text { village officials } \\
\text { 2. Review of applicable } \\
\text { SOPs by the local } \\
\text { government } \\
\text { 3. Information system } \\
\text { technology improves } \\
\text { village apparatus } \\
\text { services }\end{array}$ & $\begin{array}{l}\text { WO (Weakness \& } \\
\text { Opportunity) } \\
\text { 1. Improving village } \\
\text { apparatus services by } \\
\text { conducting leadership } \\
\text { training } \\
\text { 2. Utilization of human } \\
\text { resources to participate in } \\
\text { training in improving the } \\
\text { quality of using } \\
\text { information system } \\
\text { technology } \\
\text { 3. Improve coordination and } \\
\text { supervision of village } \\
\text { heads with other village } \\
\text { officials } \\
\text { 4. Preparation of clear SOPs } \\
\text { regarding the applicable } \\
\text { salary rules and systems. }\end{array}$ \\
\hline $\begin{array}{l}\text { Threats } \\
\text { 1. Target of improving the } \\
\text { quality of the apparatus } \\
\text { 2. Evaluate the number of } \\
\text { employees as needed } \\
\text { 3. Technology that } \\
\text { develops very fast }\end{array}$ & $\begin{array}{l}\text { ST (Strengths \& Threat) } \\
\text { 1. Increase the number of } \\
\text { employees as needed } \\
\text { 2. Applying appropriate } \\
\text { regulations to improve } \\
\text { the work discipline of the } \\
\text { apparatus } \\
\text { 3. Improving the quality of } \\
\text { human resources by } \\
\text { training the use of } \\
\text { existing information } \\
\text { systems }\end{array}$ & $\begin{array}{l}\text { WT (Weakness \& Threat) } \\
\text { 1. Prioritizing } \\
\text { educational } \\
\text { background when } \\
\text { recruiting employees } \\
\text { 2. Tighter leadership } \\
\text { supervision of the } \\
\text { apparatus. } \\
\text { 3. Given training for } \\
\text { mastery of information } \\
\text { system technology }\end{array}$ \\
\hline
\end{tabular}

Source: Data Analysis Results

Based on the results of the calculation of weight, rating and value, the total value of IFAS $=0.85(x)$ is obtained, while for the total value of EFAS $=-0.44(y)$. After getting the $x$ and $y$ values, then look for the positions shown in the SWOT quadrant. Based on the diagram, the organization of the Desar Apparatus is included in Quadrant IV (WO Strategy), so the most suitable strategy to use to improve the discipline of work of the Carawali Village apparatus is to use the WO strategy, namely:

1. Improving village apparatus services by conducting leadership training

2. Utilization of human resources to participate in training in improving the quality of using information system technology 
3. Improve coordination and supervision of village heads with other village officials

4. Preparation of clear SOPs regarding the applicable salary rules and systems.

The four strategies above can improve the work discipline of the Carawali Village Apparatus, so that if the work discipline is optimal, it will improve performance, the service to the community will also increase. Leadership training is deemed necessary, so that each village apparatus personnel can know their respective duties, so they have more responsibility for their work, and can manage time properly, so that no village apparatus comes late and leaves early.

In addition to leadership training, Computer Information Technology training was also conducted to obtain superior and quality human resources in running the existing information system in Carawali Village. So far, the existing information system has not been maximally used because only a few village apparatus personnel understand how to operate the information system. Even though this information system really supports the improvement of performance in providing services to the community and facilitates information on the current data, conditions and potential of Carawali Village.

The next strategy is to increase the coordination and supervision of the leadership, in this case the village head, with other village officials. Lack of coordination and supervision results in decreased work discipline, and organizational functions cannot run properly. Because with good coordination and supervision, the goals in village organizations will be achieved. The lack of leadership supervision will make employees act at will because they feel they will not receive a warning if they do something that is not in accordance with the applicable rules.

The fourth strategy is to make clear SOPs on the rules and salary system to be applied. Due to the absence of standard rules and a clear wage / salary system in the village of Carawali, the village apparatus has minimal staff work. For this reason, a clear SOP in accordance with the applicable Village Regulation must be done so that there are standards that are followed so that village officials know and understand the rules that must be carried out in order to achieve good performance from village officials. 


\section{Conclusion}

The most appropriate strategy in improving the work discipline of the Carawali Village Apparatus, Watangpulu District, Sidenreng Rappang Regency is improving village apparatus services by conducting leadership training, utilizing human resources to participate in training in improving the quality of using information system technology, improving coordination and supervision of village heads with officials in other villages, making clear SOPs on the rules and salary system to be applied.

\section{References}

Alawiyah Titi. (2018). Enhancing Society Civic Virtue Through Awareness of Traffic Dicipline. Proceeding of the Annual Civic Education Conference,Atlantis Press.

Dewi Susita, Wahiddah Muslimah, And Agung Aws Waspodo. (2017). The Influence Of Work Discipline And Work Environment On Organizational Commitment Employee Of Sbu Energy At Pt Biro Klasifikasi Indonesia (Persero) North Jakarta. J.Riset Manajemen Sains Indonesia, pp 275-297.

Endang Dofitria Angraini.(2019). Pengaruh Motivasi dan Disiplin Kerja terhadap Kinerja Pegawai pada Badan Pengelola Pajak dan Restribusi Daerah Muaro Jambi. J.Ilmiah Ekonomi dan Bisnis, 10 (20, pp 109-115.

Geraldino A.Sayd. (2016). Faktor-Faktor yang Mempengaruhi Kualitas Kinerja Kantor Pertanahan Rote Ndao. Jurnal Ilmu Sosial dan Ilmu Politik (JSP) Vol.19, No.3, pp 264-274.

Hayat, (2016). Peneguhan Reformasi Birokrasi melalui Penilaian Kinerja Pelayanan Publik. Jurnal Ilmu Sosial dan Ilmu Politik (JSP), Vol.20, No.2, pp 175-188.

Hendro Tjahjono. (2020). Competitive Strategy For Housing Sector Using Swot And Analytical Hierarchy Process: A Case Study Of Royale Sawangan Residence" J.Russian of Agricultural and Socio-Economic Science,pp.189-196.

Istiqomah, Al. (2017) Strategi Pengembangan Sumber Daya Manusia Sebagai Upaya Untuk Meningkatkan Kinerja Aparatur Desa Dengan Menggunakan Analisis SWOT (Studi Kasus Di Desa Pinggan, Kecamatan Bulu, Kabupaten Rembang. Universitas Negeri Malang.

Jaitun. (2013). Kinerja Aparatur Desa Dalam Penyelenggaraan Pemerintah Desa Di Desa Sepala Dalung Kecamatan Sesayap Hilir Kabupaten Tana Tidung. eJournal Pemerintahan Integratif, 2013, 1 (1): 13-27. ISSN 0000-0000. 
Kartono, Kartini (2012). Pemimpin dan Kepemimpinan Jakarta ; Penerbit PT. Grafindo Persada. Krisnajaya,I Made, et al. (2019) The Political Process of Bereaucratic Reform : Wonosobo Regional Government Experience from 2011-2015. Jurnal Ilmu Sosial dan Ilmu Politik (JSP) Vol.23,No 2. Pp 135-149.

Liando, M Daud (2012). Implementasi Kebijakan Pembentukan Daerah Otonom Baru dan Dampaknya Bagi Kualitas Pelayanan Publik. Jurnal Kebijakan dan Administrasi Publik (JKAP) Vol !6, No.2 pp 47-61.

Mulyanto. (2020) Pengaruh Motivasi Kerja, Kepuasan Kerja, dan Kompensasi Terhadap Disiplin Kerja Karyawan Kontrak Di Politeknik Negeri Jakarta Depok Jawa Barat. J.Akuntansi,Keuangan dan Perbankan, Vol 7,No.1.2841.

Mustika,Made. (2013) Analisis Strategi Peningkatan Kualitas Sumber Daya Manusia Dalam Upaya Pengentasan Kemiskinan Di Kecamatan Nusa Penida. Jurnal Buletin Studi Ekonomi, Vol. 18, No. 2, Agustus 2013. Jurusan Ekonomi Pembangunan Fakultas Ekonomi dan Bisnis Universitas Udayana.

Ngindi Fadhilah Pratiwi. (2018). Gambaran Disiplin dan Budaya Kerja Terhadap Perilaku Kewargaan Organisasional Karyawan PT. Inti (Persero) Di Bandung. J.of Business Management Education, Vol 3,No.2,pp 115-125.

Nurbaiti Beti. (2019) The Effect Of Delegation Authority, Incentive Compensation And Work Dicipline On Work Productivity Of PT Dewi Permata Perkasa.

Puspasari, Indriyani. (2017) Strategi Peningkatan Disiplin Kerja Karyawan SPBU Kartika Dewi Widiastuti (14.203.1158). Repositori Institusi USU, Univeristas Sumatera Utara.

Rita Widjaja and Eddy Supriyatna. (2020) Pengaruh Strategi Pengembangan SDM Terhadap Kinerja Karyawan. J.Manajemen Bisnis dan Kewirausahaan,Vol.4, No.2, pp 63-68.

Rivai, Veithzal, dkk. (2011) Corporate Performance Management dari Teori ke Praktek". Bogor ; Penerbit Ghalia Industri.

Robbins, Stephen P. (2003) Perilaku Organisasi. Jilid 2. Jakarta ; Penerbit PT. Indeks Kelompok Gramedia.

Salim Nur Agus. (2016) Faktor Yang Mempengaruhi Disiplin Kerja Guru (Studi Kasus Pda SMP Negeri SeKecamatan Muara Jawa. J.Pendas Mahakam, pp69-79. 
Sri Sugiharta, (2012). Desentralisasi dan Sumber Daya Aparatur : Problematika Pelaksanaan Desentralisasi Pelestarian Cagar Budaya di Provinsi Sumatera Barat, Riau, dan Kepualuan Riau. Jurnal Ilmu Sosial dan Ilmu Politik (JSP) Vol.15,No.3, pp 232-245.

Tri Widianti. (2015). Analisis Swot" Strategi Pengembangan Kelompok Penelitian. LIPI. 1-th Annual Meeting on Testing and Quality. 